Article

\title{
A Systematic Framework for Exploring Worldviews and Its Generalization as a Multi-Purpose Inquiry Framework
}

\author{
David Rousseau ${ }^{1,2,3,4, *}$ and Julie Billingham ${ }^{5,6}$ \\ Centre for Systems Philosophy, Surrey KTI5 1EL, UK \\ Centre for Systems Studies, University of Hull, Kingston-on-Hull HU6 7RX, UK \\ 3 Alister Hardy Research Centre, University of Wales TSD, Lampeter SA48 7ED, UK \\ 4 Bertalanffy Center for the Study of Systems Science, 1040 Vienna, Austria \\ 5 Centre for Systems Philosophy, Surrey KTI5 1EL, UK; julie.billingham@systemsphilosophy.org \\ 6 Salesforce, Inc., San Francisco, CA 94105, USA \\ * Correspondence: david.rousseau@systemsphilosophy.org; Tel.: +44-(0)-7714-677-687
}

Received: 31 March 2018; Accepted: 5 July 2018; Published: 10 July 2018

\begin{abstract}
Systems science methodologies do not have a consistent way of working with worldviews, even though determining stakeholder perspectives is central to systems thinking. In this paper, we propose a comprehensive "Worldview Inquiry Framework" that can be used across methodologies to govern the process of eliciting, documenting, and comparing the worldviews of stakeholders. We discuss the systemicity of worldviews and explain how this can help practitioners to find the roots of stakeholders' disagreements about value judgements. We then generalize the structure of the Worldview Inquiry Framework to produce a "General Inquiry Framework" that can be used to govern an inquiry process in other contexts. We show that the presented Worldview Inquiry Framework is a special case of this General Inquiry Framework and show how the General Inquiry Framework can be tailored for other contexts such as problem solving, product design, and fundamental research.
\end{abstract}

Keywords: worldview; systems philosophy; Worldview Inquiry Framework; General Inquiry Framework

\section{Introduction: Worldviews in the Context of Systemology}

Determining and analyzing stakeholder worldviews (also called weltanschauungen) is a key step in the methodologies of systems science. Well-known instances are as the " $\mathrm{W}$ " in the "CATWOE" analysis technique in Peter Checkland's "Soft Systems Methodology" (SSM), [1] and also as one of the two dimensions of Michael Jackson's "System of Systems Methodologies" (SOSM) [2]. As Martin Hall explained, the power of systems methodologies derive from their taking account of worldviews, because worldviews create the context both for adequate modelling of problems and for appropriate selection of solutions [3].

In the light of the importance of worldviews to systems science and its applications, it is surprising that systems science does not have a canonical ${ }^{1}$ model of the structure and dynamics of worldviews, and hence does not provide for a consistent way of working with worldviews across systems theories and methodologies. This shortcoming manifests in at least four ways.

First, different methodologies are not consistent or equally comprehensive about the aspects of worldviews they consider. For example, in SSM the "worldview question" is about what the

1 If something has canonical status, it is accepted as having all the qualities that a thing of its kind should have (Collins English Dictionary, see https://www.collinsdictionary.com/dictionary/english/canonical). 
participants perceive as the value of the project, while in SOSM, it is about the level of alignment between the attitudes of the participants to each other as well as to the project. It is peculiar that the term "worldview" should have both wide and narrow meanings within the discipline of systems science, and it begs the question of whether the methods that employ narrow applications of the term would be improved by taking a broader scope of worldview commitments into account.

Second, specific methodologies can be inconsistent in how they address the same worldview question, drawing out different worldview aspects in different instances. In fact, this even happens across projects in which the same team is employing the same methodology to address the same kind of problem within the same industry sector. An example of this covering five SSM case studies is given in [4]. Also, there are confusions amongst practitioners about what is meant by the "worldview questions" within a methodology, leading to inconsistent or trivial outcomes. This is e.g., discussed in the context of SSM in [5].

Third, "worldview considerations" are often only applied to the participants or stakeholders in the project, while little or no attention is given to the impact on the project of the worldview of the person who is leading the application of the systems methodology. Different systemologists can, depending on their worldviews, associate very different meanings to the same terms, leading to fundamentally different ways of going about selecting and applying a systems methodology. For example, a recent study found that different systems engineers attach different meanings to the term "system," and the differences reflect seven different worldviews [6,7].

Fourth, without a consistent approach to working with worldviews, researchers are free to frame their findings about stakeholder worldviews as they see fit. However, this is problematic because the way in which information is framed can profoundly influence how that information is used. This was already shown in the 1970s, when cognitive psychologists Daniel Kahneman and Amos Tversky applied framing in experimental designs to understand risk judgments and consumer choices, producing Nobel Prize-winning research that concluded that "perception is reference dependent." This research showed that if individuals are reflecting on an ambiguous or uncertain situation then different ways in which a message is presented or framed (e.g., using different terminologies or different visual presentations) can-apart from the content itself-result in very different responses [8].

It has to be acknowledged that this situation is not unique to systems science, and the worldview concept is often applied very narrowly or inconsistently in other disciplines too (e.g., anthropology, sociology and religious studies). For example, "worldview" can be used to refer only to people's religious beliefs, or their moral commitments, or their stances on human rights.

This situation is somewhat understandable. Academic interest in "worldview" as a subject originated in late 18th century philosophy, but remained a minority interest outside of philosophy and theology until the 20th century, when it became important first in psychology (early 20th century) and then from the mid-20th century more widely in areas such as cultural anthropology, religious studies, the social sciences, and epistemology [9]. This wider interest in worldviews therefore only arose in academia around the time of the establishment of systems science as an academic endeavor (ca. 1950), and arguably only become significant in academic discourse in the last decades of the 20th century, notably due the work of Thomas Kuhn on the nature of paradigm change in science (1960s onward) [10,11], and the "science wars" of the 1990s, when differences between scientific realists and postmodernist critics about the nature of scientific theory and intellectual inquiry became prominent in the academic and mainstream press [12].

It can therefore be considered that it is only in the last twenty years or so that academic studies on worldviews have become sufficiently deep, rich, and balanced to form a practical basis for developing a principled worldview model that can be operationalized across the methodologies of systems science. 
In our view, a more comprehensive worldview documentation method could help to make systems methodologies more effective and more reliable [13,14]. ${ }^{2}$ It could also help to expand the use of systems research methodologies into areas currently lacking in systems methodologies, such as frontier science (where the implications of new theories may be challenging to contemporary worldviews) $[15-18]^{3}$ or social transformation (for example, where technologically driven change is disrupting the worldviews on which contemporary social and political structures and processes depend) [19]. ${ }^{4}$

In this paper, we will present a proposal for a thorough worldview framework, based on analyzing and integrating inputs from a range of academic fields. We will argue that our framework represents worldviews comprehensively because it captures the main kinds of knowledge at stake in any scenario. This insight allows us to generalize it into a framework for gathering information in any context where there is uncertainty, risk or ambiguity. The present paper has two main objectives. The first is to present and explain these frameworks as a contribution toward establishing a comprehensive worldview inquiry framework for use in the systems field. The second is to show how this opens the way for establishing a general inquiry framework for use in multiple contexts.

We believe that using frameworks such as these could make systems methodologies more effective, more reliable, and more consistent, and that this will increase the perceived value of systems science in research, design, and intervention.

\section{General Background on Worldviews}

\subsection{The Meaning and Importance of Worldviews}

The term "worldview" is the English rendering of the term Weltanschauung. The term Weltanschauung was coined by Immanuel Kant in 1790 [20] (pp. 111-112), and it rapidly developed as "a term for an intellectual conception of the universe from the perspective of a human knower" [9] (p. 59). The term worldview has a rich academic history, and a dappled application of terminology, which we will not review here. For comprehensive surveys, see $[9,21,22]$.

The term worldview is used differently in different disciplines, typically in each case in order to emphasize a particularly relevant aspect, so that, for example, in management science, "worldview" is typically taken to be about an individual or group's value system, while in theology, "worldview" is often taken to be an individual's view about the existence and nature of God. However, worldviews are richer constructs that these uses suggest. Personal worldviews evolve as people try to integrate their knowledge, experience, and intuitions into a coherent framework they can use to make sense of their lives and make decisions about how to live and what to do [21,23,24]. A worldview, then, is the overall perspective from which one sees and interprets the world in all its diversity and complexity. It functions as a "map of reality" that people use to order their lives $[9,21,22,25,26]$.

In this sense, the scope of worldviews covers all the domains of experience, decision-making, and action and covers all the kinds of information we might have about the nature of the world and our place in the scheme of things.

The general significance of worldviews lies in this: everyone has one, and it constitutes a set of beliefs that guides their judgment making and action taking in all spheres of activity. Different people have different worldviews, and individual worldviews change and develop on an ongoing basis. It is common to find worldview referred to as "a philosophy," meaning a personal philosophy. As G.K Chesterton expressed it,

2 For a discussion of concerns about the success rate and reliability of systems methodologies, see e.g., [13,14].

Unexplained phenomena such as consciousness, creativity, intuition, and savant syndrome present clear examples. See e.g., [15-17]. For discussion about the lack of suitable methods for effective frontier research, see e.g., [18].

4 The rising tide if the so-called 'Fourth Industrial Revolution' is clear evidence of the need for methodologies to anticipate and manage social change in the face of technological advances. See, e.g., [19]. 
There are some people-and I am one of them-who think that the most practical and important thing about a man is still his view of the universe. We think that for a landlady considering a lodger it is important to know his income, but still more important to know his philosophy. We think that for a general about to fight an enemy it is important to know the enemy's numbers, but still more important to know the enemy's philosophy. We think the question is not whether the theory of the cosmos affects matters, but whether in the long run anything else affects them [27] (pp. 15-16).

Worldviews, or significant portions of a worldview, could be held in common between members of a community, and in this case it is usually referred to as a "paradigm." A familiar example is "the scientific paradigm" as discussed by Thomas Kuhn [10].

\subsection{The Complexity and Dynamics of Worldviews}

The formation and ongoing adaptation of worldviews is a complex process, in which people integrate knowledge, experiences, and intuitions into a more-or-less coherent whole. The apparent implications of knowledge, personal experiences and intuitions are not always in complete agreement, so this balancing reconciliation is not a simple process, and tends to be under constant revision as more knowledge and experiences are gained. This is an autonomic and largely subconscious process, and for most people, the results are held subconsciously too, so people are typically not explicitly aware of everything in their worldview [25]. This makes it a difficult task in practice to characterize someone's worldview.

Moreover, individual worldviews cannot be classified in a simple way because someone's commitments in one area do not determine (although they do condition) what their commitments might be in another area [28]. For example, someone may be a scientific realist about the material world (i.e., believe that the physical world has an objective existence and we can gain universally valid knowledge about it through science) while being a social constructivist about the nature of values (i.e., hold that values reflect only subjective agreements made within social groups). We will say more about the systemic aspects of a worldview later on, after we have characterized the components of a worldview.

\subsection{Paradigms}

While a worldview is a personal philosophy, it is usually not completely unique per person. As mentioned above, when a group of people hold a worldview in common then it (or the part of it held in common) is called a "paradigm," and hence we have such designations as the "scientific paradigm," "the Christian paradigm," a "research paradigm," etc. There is a rising interest in paradigms in areas such as peace education, sustainable development, social policy and so on, and from work in these areas, and areas more historically interested in worldviews such as theology, we now have several models in the academic literature documenting paradigmatic worldviews (i.e., types of paradigms and comparisons between their tenets) or paradigmatic approaches to specific worldview components, e.g.:

- A comparison between the paradigms of Traditional, Modern, Postmodern, and Integrative Worldviews [29];

- A comparison between the paradigms of Christian Theism, Secular Postmodernism, Pantheistic Monism, Islamic Theism [30];

- A comparison between different paradigmatic tenets regarding the nature of knowledge, namely from the perspectives of Idealism, Physicalism, Emergentism, Constructivism, Intuitionism, Theism, and Critical Realism [31].

There also now exists good scholarship on the subject of how to develop and validate measures of people's worldview beliefs $[29,32]$ and how to analyze results of such surveys, e.g., to test the coherence of a worldview or to expose their potentials and pitfalls [29,30,33,34]. 
However, across this academic space, there is substantial variety in what academics identify as the components of a worldview. As we will show later on, there is substantial overlap between different models but also significant differences and omissions. We suppose that to some degree this reflects the interests or motivations of the researchers. Checkland's SSM discussed above provides a case in point, for although the methodology on the face of it claims to be documenting the stakeholder's weltanschauung, in fact it only tries to establish what the stakeholder would value in the project outcome. Checkland has confirmed that SSM's "worldview" interest is meant to be narrow in this way [35], but practitioners have suggested that a more comprehensive worldview exploration would improve the quality of the analysis [5].

\section{The "Worldview Inquiry Framework"}

\subsection{Development of the Worldview Inquiry Framework}

We have been doing research for several years into the structure and systemicity of worldviews, the concepts employed to frame the tenets that make up a worldview, and how these tenets systemically interdepend. Initially our motivation was to understand how worldviews might be challenged by research findings in frontier science, but as we developed the framework we realized that it might be a useful contribution to all of the fields we have drawn on in developing it, including anthropology, religious studies, social science, theology, cosmology, psychology, philosophy, and systemology, e.g., $[9,21,22,25,29,30,34,36-49]$. We realized early on that systemology would provide a natural home for our work in this area, because:

- a worldview is a system and hence is most appropriately studied from a system perspective;

- systems science and systems thinking contain many methodologies for which consideration of aspects of worldviews is essential irrespective of the problem context, so systemology provides an active and diverse community with whom to engage; and

- $\quad$ systemology is a transdiscipline, and hence it is part of its objectives to develop tools that can be applied across disciplines and contexts.

In order to develop our understanding of the structure, systemicity and conceptual terrain of worldviews, we drew extensively on philosophical literature (especially ontology and metaphysics) to find ways of reconciling different uses of the same terms (e.g., what is meant by terms such as existence, purpose, God, matter, value, etc.). From the outset, we were convinced that it would be possible to arrive at a usefully consilient outcome, despite the diversity of perspectives, terminologies, and purposes presented in the academic literature on worldviews. Over the period of our study, we and our collaborators presented various aspects or early models of our emerging perspective on worldviews in publications, workshops, seminars, and conference presentations, e.g., [28,31,50-59]. In this paper, we bring together, and extend, the high-level findings of this research programme. We were also able to generalize our approach to exploring worldviews to create a framework for exploring information categories in other scenarios, which we have presented in a paper and a workshop $[60,61]$ that inspired two case studies, the results of which are scheduled for presentation at two upcoming conferences $[62,63]$.

\subsection{High-Level Overview of the Worldview Inquiry Framework}

We now present, at high level, our Worldview Inquiry Framework in Table 1. Each row illustrates aspects of one component of a worldview. In the first column, we provide our recommended categories for the components of a worldview. This choice of categories was driven by the need to separate the components in a clear way while remaining as close as possible to the divisions suggested by 
other researchers [64]. ${ }^{5}$ Please note that the terms used for these categories have multiple meanings in standard usage. For example, "axiology" typically refers to a philosophical discipline concerned with the nature of values, investigating what values are, how they arise, how they are applied, and what their criteria of merit are. Against this, a particular person may have various "axiological beliefs" that represent their personal value system and beliefs about what an appropriate grounding for a value system is. This set of beliefs then forms that person's "axiology," i.e., the values-related component of their personal philosophy. This latter sense of the term is intended in Table 1, but it should usually be clear from the context how the category terms are to be understood.

The second column illustrates the kinds of questions that are the focus of each worldview category, and column 3 gives an overview of the scope of the inquiry in each category. To frame appropriate questions and relevant beliefs one needs appropriate concepts, and we give some examples for each category in column 4 . The aim of an inquiry into worldviews is to explore the beliefs a person holds in each category, and we give some examples of possible answers one might receive in column 5 . Note that these are illustrative examples only and are not a set meant to represent any specific worldview, and we do not intend with these examples to recommend some beliefs over others. For example, in row 4 (cosmology of nature), the illustrated belief that physical nature arose via the Big Bang and has since evolved naturalistically is one possible option for a belief about the origin and history of nature, but others options also exist e.g., the belief that physical nature was created by and is unfolding under the governance of God, or that physical nature is an illusion arising within a personal or universal consciousness, or some combination of such beliefs. The plausibility or coherence of alterative options are not here at stake, and can only be assessed in the light of beliefs in other components (e.g., epistemological commitments about what counts as authoritative sources of knowledge and why).

Note that, from an information-gathering perspective, the logical sequence in which the components are addressed can be rearranged to suit the context, so there is no special significance to the sequence of the rows in Table 1. For example,

- for systemic intervention, the system practitioner might be primarily interested in what stakeholders value, in which case the analysis will start with axiology;

- for teamwork, the leader might be interested in each member's perspective on their role in the team, so would start their inquiry with praxeology; and

- for frontier research, the scientist might be primarily interested in how new theoretical insights might impact the scientific paradigm and hence would start their inquiry with ontology or metaphysics.

Note also that the extent to which information needs to be gathered in any area depends on the needs of the particular inquiry. The framework provides a guide to options, but it is not obligatory to pursue them all. For example, in a systemic intervention, different stakeholders may have different reasons for considering a project important, but these may not be in conflict with each other, in which case, the project can proceed in a consensual way (e.g., in a railway project the same solution can provide both jobs for the locals and a low-carbon transport system for the economy). However, if the stakeholder values are conflictual, then the inquiry will have to "dig deeper" in order to expose the roots of the conflict and mediate a resolution (e.g., in a railway project, the environmental harm of building the railway system must be reconciled with the social benefit of the project).

5 The most controversial case is the ontology/metaphysics split. In the philosophical literature, some academics regard the ontology/metaphysics division as superfluous and settle for just the one or the other, some regard ontology as a subset of metaphysics, some regard metaphysics as a subset of ontology, and some regard the split as meaningful but only one of the two to be a feasible undertaking. For an accessible discussion, see [64]. A basic illustration of the possible distinction is this: the claim that "gravity" exists, and claims about what its identifying features are, are ontological claims; claims about the nature of gravity (e.g., that it is a force field or a curvature in space) are metaphysical claims. 
Table 1. A framework for cataloguing the components of a worldview.

\begin{tabular}{|c|c|c|c|c|}
\hline Worldview Component & Key Question & Content Scope & Relevant Concepts & Examples of Worldview Commitments \\
\hline Ontology & $\begin{array}{l}\text { What kinds of substances exist most } \\
\text { fundamentally? What grounds the } \\
\text { existence of reality? }\end{array}$ & $\begin{array}{l}\text { Theory about what exists most } \\
\text { fundamentally; Models of } \\
\text { identifying characteristics }\end{array}$ & $\begin{array}{l}\text { Space, time, matter, minds, God, } \\
\text { Akasha, Apeiron, consciousness }\end{array}$ & $\begin{array}{l}\text { All concrete things are physical particles } \\
\text { or composites of them }\end{array}$ \\
\hline Metaphysics & $\begin{array}{l}\text { What is the nature of the } \\
\text { fundamental existents? }\end{array}$ & $\begin{array}{l}\text { Theory about the powers, } \\
\text { limitations and dynamics of } \\
\text { what exists (and hence what is } \\
\text { possible given the ontology) }\end{array}$ & $\begin{array}{c}\text { Energy, lawfulness, } \\
\text { real/imaginary, concrete/abstract, } \\
\text { natural/supernatural }\end{array}$ & $\begin{array}{l}\text { An objective reality exists; All changes } \\
\text { have lawful causes }\end{array}$ \\
\hline $\begin{array}{c}\text { Cosmology I } \\
\text { (Cosmology of Nature) }\end{array}$ & $\begin{array}{l}\text { What is the nature, origin, } \\
\text { developmental history and } \\
\text { potential of the natural world? }\end{array}$ & $\begin{array}{l}\text { High-level theory about the } \\
\text { origin, history, current state \& } \\
\text { activity, future and destiny } \\
\text { of nature }\end{array}$ & $\begin{array}{l}\text { Big bang, creation, evolution, } \\
\text { systems hierarchy, expansion, } \\
\text { heat death, transcendence }\end{array}$ & $\begin{array}{l}\text { The world arose at the Big Bang and } \\
\text { evolves in accordance with } \\
\text { naturalistic laws. }\end{array}$ \\
\hline $\begin{array}{c}\text { Cosmology II } \\
\text { (Cosmology of Persons) }\end{array}$ & $\begin{array}{l}\text { What is the nature, origin, } \\
\text { developmental history and } \\
\text { potential of human beings? }\end{array}$ & $\begin{array}{l}\text { High-level theory about the } \\
\text { origin, history, current state \& } \\
\text { activity, future and destiny of } \\
\text { human beings }\end{array}$ & $\begin{array}{c}\text { Evolution, reproduction, } \\
\text { development, sentience, memory, } \\
\text { will, agency, freedom, rationality, } \\
\text { cognition, judgement, } \\
\text { intentionality, wisdom }\end{array}$ & $\begin{array}{l}\text { Human beings are animals with } \\
\text { sentience, free will, agency, rationality, } \\
\text { rights and duties }\end{array}$ \\
\hline Axiology & $\begin{array}{l}\text { What is important and why? } \\
\text { What makes something 'good'? }\end{array}$ & $\begin{array}{l}\text { Theories about what is good or } \\
\text { important and why }\end{array}$ & $\begin{array}{c}\text { Values, ethics, morality, aesthetics, } \\
\text { social construction, utility theory, } \\
\text { natural law theory, divine } \\
\text { command theory }\end{array}$ & $\begin{array}{l}\text { All sentient beings have the right to life } \\
\text { and freedom }\end{array}$ \\
\hline Praxeology & $\begin{array}{l}\text { How should we live? What gives } \\
\text { action meaning? What are our } \\
\text { purposes and how can we } \\
\text { achieve them? }\end{array}$ & $\begin{array}{l}\text { Theories about what is } \\
\text { meaningful or purposeful action } \\
\text { and why. Action principles and } \\
\text { theories about agency, freedom } \\
\text { and responsibility }\end{array}$ & $\begin{array}{l}\text { Free will, choice, agency, freedom, } \\
\text { responsibility, duty, best practice }\end{array}$ & $\begin{array}{c}\text { We are responsible for our choices and } \\
\text { our actions }\end{array}$ \\
\hline Epistemology & What/how can we (not) know? & $\begin{array}{l}\text { Theories about what kinds of } \\
\text { knowledge are possible and } \\
\text { how to gain knowledge }\end{array}$ & $\begin{array}{l}\text { Science, sacred texts, cultural } \\
\text { authority, intuition, mystical } \\
\text { revelation, experience }\end{array}$ & $\begin{array}{l}\text { The scientific method can progressively } \\
\text { reveal the truth about all real phenomena }\end{array}$ \\
\hline
\end{tabular}




\subsection{Comparison with Other Worldview Models}

With the clarifications given in Table 1 in mind, we can now compare the Worldview Inquiry Framework with representative examples of other worldview frameworks, as given in Tables 2 and 3. We have selected only proposals with a reasonably rich structure, each containing at least five components. Most literature sources discuss only 1-3 components. For reasons of space, we present the comparative data across two tables, and align them by repeating the first column. As will be seen in Table 2 Part 1 and Part 2, the other worldview framework proposals map fairly well onto the components and questions of the Worldview Inquiry Framework but are not as comprehensive. For reference purposes we list in the first row the name of the author, the key years of publication of their framework, a citation of the key publication, their description of what their framework is about (in curly brackets), and the discipline they are from (in triangular brackets). Where authors have categorized their worldview questions, we report their category labels. Sometimes, their questions under one label span several categories of our framework, and in such cases, we split their categories and numbered the segments to indicate the fragments. Where authors have numbered their own subdivisions, we use their numbering (a case in point is de Witt et. al. in Part 2 column 4).

Note to Table 2 Part 2: The questions reported in Column 4 for the Integrative Worldview Framework (IWF) are paraphrased by us to represent what we take to be the intent of groups of survey questions in the IWF. We formulated this paraphrase to enable comparison with other frameworks, but we acknowledge that de Witt et al. might summarize the intent of each question set differently. In the other columns of Table 2 (Parts 1 and 2), we use the researchers' own expressions in posing their questions or propositions.

The comparisons given in Table 2 demonstrate that the other frameworks are subsets or special cases of our proposed framework and hence that our framework could stand in for any of these other application areas. On this basis, we conclude that our proposed worldview framework is comprehensive in scope, and hence would be suitable for use in any context where worldviews, or aspects of worldviews, are at issue.

\subsection{An Extended Worldview Inquiry Framework}

To make the Worldview Inquiry Framework easier to use, it is helpful to expand each component into subsections under which related questions can be grouped. To frame appropriate questions, and document their answers, specific concepts are needed, and it would be helpful to develop a standard set of concepts so this work can be done in a consistent way. We make a first proposal along these lines in Figure 1, where we use the Worldview Inquiry Framework to give structure to a concept map that identifies some of the relevant concepts in each area. Further work is needed to refine the concept lists and disambiguate each concept, and we elsewhere discuss a methodology for doing such work [66]. This is an important task still to be done, because as mentioned in the Introduction, it is known that presentation format and terminology affect how people respond to information even beyond the content of the information.

As we noted above, there are good methods already present in academia for developing worldview questions, validating the survey instruments and analyzing the interview results. What was lacking, in our view, was

- a comprehensive but succinct framework on which to base such surveys;

- a consistent set of concepts for formulating worldview questions and documenting beliefs.

The tools we have introduced so far in this paper are offerings toward closing these gaps. 
Table 2. A comparison of different proposals for cataloguing the components of a worldview.

\begin{tabular}{|c|c|c|c|c|}
\hline \multicolumn{5}{|c|}{ Part 1 } \\
\hline $\begin{array}{l}\text { Rousseau \& Billingham (2018) } \\
\text { \{The Worldview Inquiry Framework\} } \\
\text { <Systems Philosophy, Science> }\end{array}$ & $\begin{array}{c}\text { Ken Funk (2001) [40] } \\
\{\text { The elements of one's worldview }\} \\
<\text { Engineering }>\end{array}$ & $\begin{array}{l}\text { Clement Vidal (2008) [38] } \\
\text { \{Fundamental questions, and the } \\
\text { disciplines that try to answer them } \\
\text { <Evolutionary Cosmology> }\end{array}$ & $\begin{array}{c}\text { James Sire }(1976,2004)[22,36] \\
\{\text { Questions every worldview } \\
\text { should answer\} } \\
<\text { Theology }>\end{array}$ & $\begin{array}{c}\text { Diederik Aerts et al. (1994) [39] } \\
\{\text { The components of a worldview }\} \\
\text { <Physics> }\end{array}$ \\
\hline $\begin{array}{l}\text { Ontology } \\
\text { (What exists to generate the world? What } \\
\text { provides the conditions for the possibility } \\
\text { of the existence and nature of the world?) }\end{array}$ & $\begin{array}{l}\text { Theology 1: beliefs about the } \\
\text { existence of God }\end{array}$ & $\begin{array}{l}\text { What is? (Ontology—-model of reality as } \\
\text { a whole) }\end{array}$ & $\begin{array}{l}\text { What is prime } \\
\text { reality—-the really real? }\end{array}$ & - \\
\hline $\begin{array}{c}\text { Metaphysics } \\
\text { (What is the nature/character of the } \\
\text { fundamental existent(s)?) }\end{array}$ & $\begin{array}{c}\text { Metaphysics: beliefs about the } \\
\text { ultimate nature of Reality } \\
\text { Theology 2: beliefs about the nature } \\
\text { of God }\end{array}$ & - & $\begin{array}{l}\text { What is the nature of external } \\
\text { reality, that is, the world around us? }\end{array}$ & $\begin{array}{l}\text { Why is our world the way it is, and } \\
\text { not different? Why are we the way } \\
\text { we are, and not different? }\end{array}$ \\
\hline $\begin{array}{l}\text { Cosmology I } \\
\text { (Cosmology of Nature) } \\
\text { (What is the nature of nature? What is its } \\
\text { origin, scope, history and potential? }\end{array}$ & $\begin{array}{l}\text { Cosmology: beliefs about the origins } \\
\text { and nature of the universe; Teleology: } \\
\text { beliefs about the meaning and } \\
\text { purpose of the universe, its inanimate } \\
\text { elements, and its inhabitants }\end{array}$ & $\begin{array}{c}\text { Where does it all come from? } \\
\text { (Explanation-model of the past) } \\
\text { Where are we going? (Prediction-model } \\
\text { of the future) }\end{array}$ & - & $\begin{array}{l}\text { What is the nature of our world? } \\
\text { How is it structured and how does } \\
\text { it function? }\end{array}$ \\
\hline $\begin{array}{c}\text { Cosmology II } \\
\text { (Cosmology of Persons) } \\
\text { (What is the nature, origin, history and } \\
\text { potential of persons?) }\end{array}$ & $\begin{array}{l}\text { Cosmology: beliefs about the origins } \\
\text { and nature of life and Man; }\end{array}$ & - & $\begin{array}{l}\text { What is a human being? What } \\
\text { happens to a person at death? }\end{array}$ & $\begin{array}{l}\text { What future is open to us and our } \\
\text { species in this world? By what } \\
\text { criteria are we to select these possible } \\
\text { futures? How, in what different ways, } \\
\text { can we influence the world? }\end{array}$ \\
\hline $\begin{array}{l}\text { Axiology } \\
\text { (What is important and why) }\end{array}$ & $\begin{array}{l}\text { Axiology: beliefs about the nature of } \\
\text { value, what is good and bad, what is } \\
\text { right and wrong }\end{array}$ & $\begin{array}{l}\text { What is good and what is evil? } \\
\text { (Axiology-theory of values) }\end{array}$ & $\begin{array}{l}\text { How do we know what is right } \\
\text { and wrong? }\end{array}$ & - \\
\hline $\begin{array}{c}\text { Praxeology } \\
\text { (How should we act and why) }\end{array}$ & $\begin{array}{l}\text { Anthropology: beliefs about the } \\
\text { nature and purpose of Man in general } \\
\text { and, oneself in particular }\end{array}$ & $\begin{array}{l}\text { How should we act? } \\
\text { (Praxeology-theory of actions) }\end{array}$ & $\begin{array}{l}\text { What is the meaning of human } \\
\text { history? What personal, } \\
\text { life-orienting core commitments are } \\
\text { consistent with this worldview? }\end{array}$ & $\begin{array}{c}\text { How are we to act and to create in } \\
\text { this world? What are the general } \\
\text { principles by which we should } \\
\text { organise our actions? }\end{array}$ \\
\hline $\begin{array}{c}\text { Epistemology } \\
\text { (What can we know? How and why?) }\end{array}$ & $\begin{array}{l}\text { Epistemology: beliefs about the } \\
\text { nature and sources of knowledge }\end{array}$ & $\begin{array}{l}\text { What is true and what is false? } \\
\text { (Epistemology-theory of knowledge) }\end{array}$ & $\begin{array}{l}\text { Why is it possible to know anything } \\
\text { at all? }\end{array}$ & $\begin{array}{l}\text { Why do we feel the way we feel in } \\
\text { this world, and how do we assess } \\
\text { global reality, and the role of our } \\
\text { species in it? How are we to construct } \\
\text { our image of this world? }\end{array}$ \\
\hline
\end{tabular}


Table 2. Cont.

\begin{tabular}{|c|c|c|c|c|}
\hline \multicolumn{5}{|c|}{ Part 2} \\
\hline $\begin{array}{l}\text { Rousseau \& Billingham (2018) } \\
\text { \{The Worldview Inquiry Framework\} } \\
\text { <Systems Philosophy, Science> }\end{array}$ & $\begin{array}{c}\text { Ninian Smart (1981) [37] } \\
\{\text { Dimensions of every religious worldview }\} \\
\text { <Religious Studies> }\end{array}$ & $\begin{array}{l}\text { Mario Bunge (2009) [65] } \\
\text { \{The branches of an } \\
\text { authentic philosophy\} } \\
\text { <Scientific Philosophy> }\end{array}$ & \begin{tabular}{|c|} 
Annick De Witt et al. \\
(2016) [29] \{The aspects of \\
'The Integrative Worldview Framework'\} \\
<Sustainable Development> \\
\end{tabular} & $\begin{array}{c}\text { Kenneth Samples } \\
\text { (2007) }[30]\{\text { The major components of } \\
\text { a worldview }\} \\
<\text { Theology> } \\
\end{array}$ \\
\hline $\begin{array}{l}\text { Ontology } \\
\text { (What exists to generate the world? What } \\
\text { provides the conditions for the possibility } \\
\text { of the existence and nature of the world?) }\end{array}$ & Doctrinal or philosophical dimension & Ontology 1: being & - & $\begin{array}{l}\text { Theology - Concept of God, } \\
\text { or absence of such }\end{array}$ \\
\hline $\begin{array}{c}\text { Metaphysics } \\
\text { (What is the nature/character of the } \\
\text { fundamental existent(s)?) }\end{array}$ & Doctrinal or philosophical dimension & Ontology 2: becoming & $\begin{array}{l}\text { Ontology } 1 \text { - Metaphysics: What is the } \\
\text { nature of reality? }\end{array}$ & $\begin{array}{l}\text { Metaphysics-View of } \\
\text { external reality, especially the cosmos }\end{array}$ \\
\hline $\begin{array}{c}\text { Cosmology I } \\
\text { (Cosmology of Nature) } \\
\text { (What is the nature of nature? What is its } \\
\text { origin, scope, history and potential? }\end{array}$ & Narrative or mythical dimension & - & $\begin{array}{l}\text { Ontology 3: How did life originate? } \\
\text { Ontology 4: What is the nature of nature? }\end{array}$ & $\begin{array}{l}\text { History—Study of the nature, } \\
\text { direction and purpose of unfolding } \\
\text { historical events }\end{array}$ \\
\hline $\begin{array}{c}\text { Cosmology II } \\
\text { (Cosmology of Persons) } \\
\text { (What is the nature, origin, history and } \\
\text { potential of humans?) }\end{array}$ & Narrative or mythical dimension & - & $\begin{array}{c}\text { Anthropology 1, 2, 3, 6: What defines } \\
\text { who I am? What is a human being? What } \\
\text { the humans' relationship to nature? What } \\
\text { happens to us at death? }\end{array}$ & $\begin{array}{l}\text { Anthropology-Study of the origin, } \\
\text { nature, problems and destiny of } \\
\text { human beings }\end{array}$ \\
\hline $\begin{array}{l}\text { Axiology } \\
\text { (What is important and why) }\end{array}$ & Ethical or legal dimension & $\begin{array}{l}\text { Axiology: values; } \\
\text { Ethics: rights and duties }\end{array}$ & $\begin{array}{l}\text { Ontology 2-What is the value of nature? } \\
\text { Axiology 1,2: What is important to me? } \\
\text { What motivates my attitudes? } \\
\text { Anthropology 4: What rights and } \\
\text { obligations do we have about nature? } \\
\text { Societal vision 1,2: What is our role in } \\
\text { society? What are our rights and duties } \\
\text { in society? }\end{array}$ & $\begin{array}{l}\text { Axiology -Study of the origin, } \\
\text { nature, meaning and criteria of values }\end{array}$ \\
\hline $\begin{array}{c}\text { Praxeology } \\
\text { (How should we act and why) }\end{array}$ & $\begin{array}{l}\text { Ritual or practical dimension; Social or } \\
\text { institutional dimension }\end{array}$ & Praxeology: action & $\begin{array}{l}\text { Axiology } 3,4: \text { What do I value in life? } \\
\text { What is my preferred lifestyle? } \\
\text { Anthropology 5: Why do we suffer? }\end{array}$ & \\
\hline $\begin{array}{c}\text { Epistemology } \\
\text { (What can we know? How and why?) }\end{array}$ & Experiential or emotional dimension & $\begin{array}{l}\text { Epistemology: cognition and knowledge; } \\
\text { Logic: precision and deducibility; } \\
\text { Semantics: meaning and truth; } \\
\text { Methodology: evidence; } \\
\text { Philosophy of Science } \\
\end{array}$ & $\begin{array}{c}\text { Epistemology 1,2, 3: } \\
\text { What is the role of science? What are the } \\
\text { impacts of science and technology? } \\
\text { Who/what can I trust about what } \\
\text { to believe? }\end{array}$ & $\begin{array}{l}\text { Epistemology-Study of the origin, } \\
\text { nature, limits and validity } \\
\text { of knowledge }\end{array}$ \\
\hline
\end{tabular}




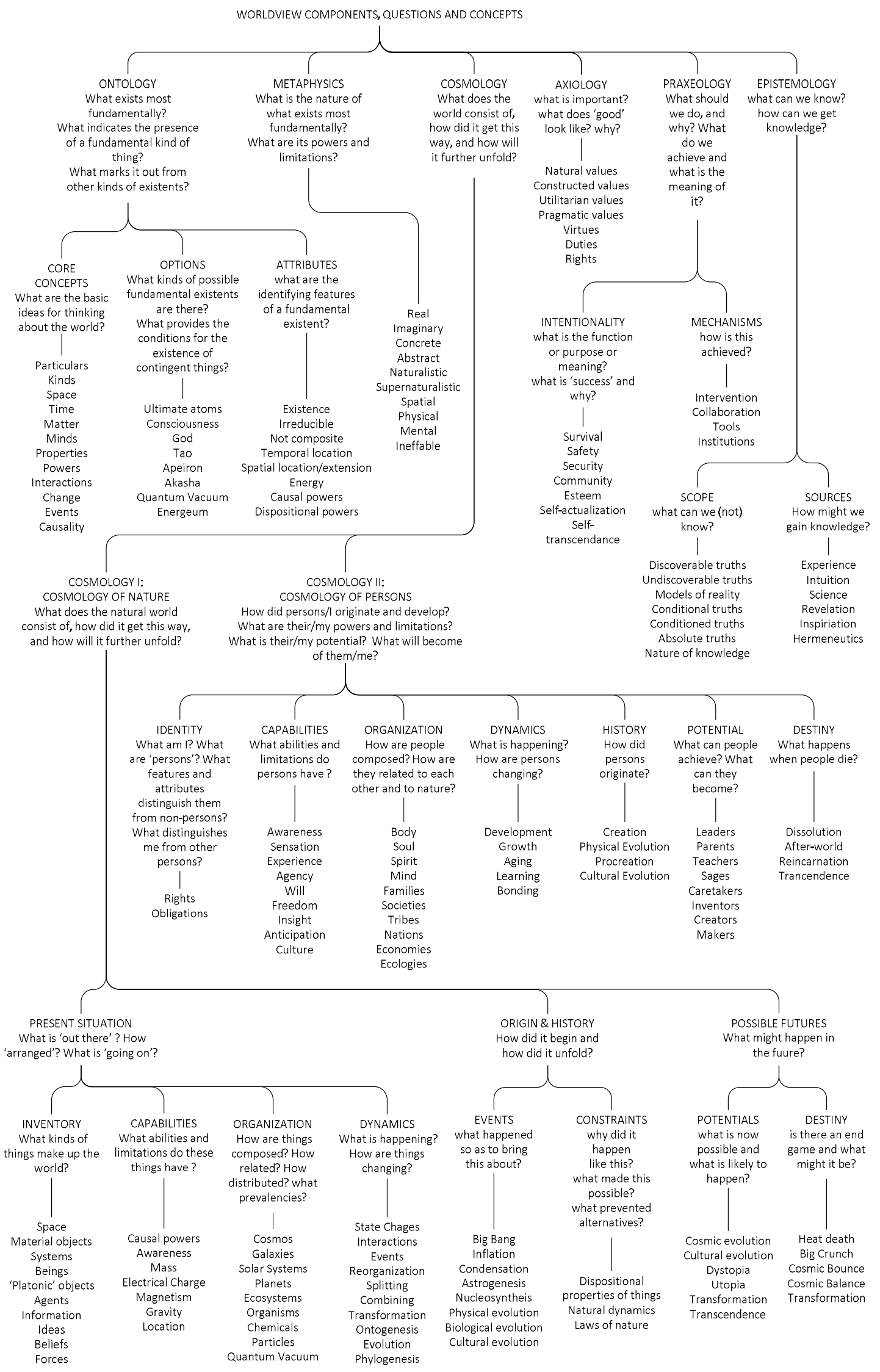

Figure 1. An extended Worldview Inquiry Framework and a mapping of relevant concepts. 


\section{The World as a System, Modelled in Terms of the Worldview Inquiry Framework}

We earlier mentioned that worldviews are systems without defending or exploring that assessment. However, now that we have defined the components of a worldview and their correlated areas of belief, we can return to consider the nature and the implications of the systemicity of worldviews in more detail.

According to one systems definition, due to Anatol Rapoport and popular in the systems science community, a system as a whole that functions as a whole because of the interactions between its parts [67]. This is consistent with the definition of systems now emerging in the systems engineering community, according to which "A physical system is a structured set of parts or elements, which together exhibit behaviour that the individual parts do not" and "A conceptual system is a structured set of parts or elements, which together exhibit meaning that the individual parts do not" $[6,68]$.

In the sense of these definitions a worldview is a conceptual system. A worldview's systemicity is evident in the way that the content of the components of a person's worldview change not only to accommodate new information but to strive toward coherence-that is, to make sense as a whole. It is also evident on a larger scale, where, as Thomas Kuhn explained, paradigm shifts occur when the coherence of a current paradigm (a worldview shared by a group) cannot be maintained given cumulative new evidence and current beliefs, and hence a shift to a new balance is triggered. This happens via a "revolution" that adjust beliefs so as to incorporate the new evidence in a way that allows the overall set of adjusted beliefs to come back into coherence as a whole [10].

Of course, a worldview is not only a conceptual system but also a "map of reality," a view on the actual world, which (at least under the perspective of scientific realism) is a system also, and a worldview is a model of the structure and coherence of the concrete world, in the sense of Robert Rosen's "modelling relationship" [69].

It is instructive to sketch a "systems model" of the world in terms of the components and interdependencies of the Worldview Inquiry Framework proposed earlier. In Figure 2, we present a diagram that shows one way of illustrating some of the correspondences between the components of a worldview (right hand side) and the aspects of the world that they represent (left hand side) together with some of their interdependencies (linking arrows).

This is not a unique or a comprehensive model of the systemicity of the world, but it is sufficient for illustrating the basis of the implications we draw out below.

Recognizing that worldviews are conceptual systems and that they model a systemic world, and being able to provide a comprehensive framework for representing this, are valuable advances for two reasons.

First, the structure of the model tells us something important about how worldviews underpin people's behavior. We can see here that actions depend on judgments, which in turn depend on values. Values depend on beliefs about the nature of people and the world, natures that are manifested via their powers and limitations. The existence of people and the world, and their powers and limitations, depends in turn on the types and natures of ultimate substances. The implication is that people's values depend deeply on their ontological and metaphysical beliefs. This is clearly seen in how people's assessments of the meaning of their lives and their actions vary depending on whether they consider "ultimate reality" to be, e.g., physical matter, or consciousness, or an alien simulation programme, or God. From a scientific perspective the nature of "ultimate reality"is far from settled, and hence we have ongoing controversies and conflicts about meanings, rights, and duties across different stakeholder communities. This underscores the importance of current research into these "frontier areas" [50,70-72]. For the moment, though, understanding the dependencies among components of a worldview is important for systems practitioners because, in the case of conflicts between stakeholder perspectives, it enables the practitioner to trace the roots of those differences via these dependencies, and hence places the practitioner in a position to facilitate a conversation between the stakeholders to bring about convergence of or at least mutual understanding or respect for these differences. 


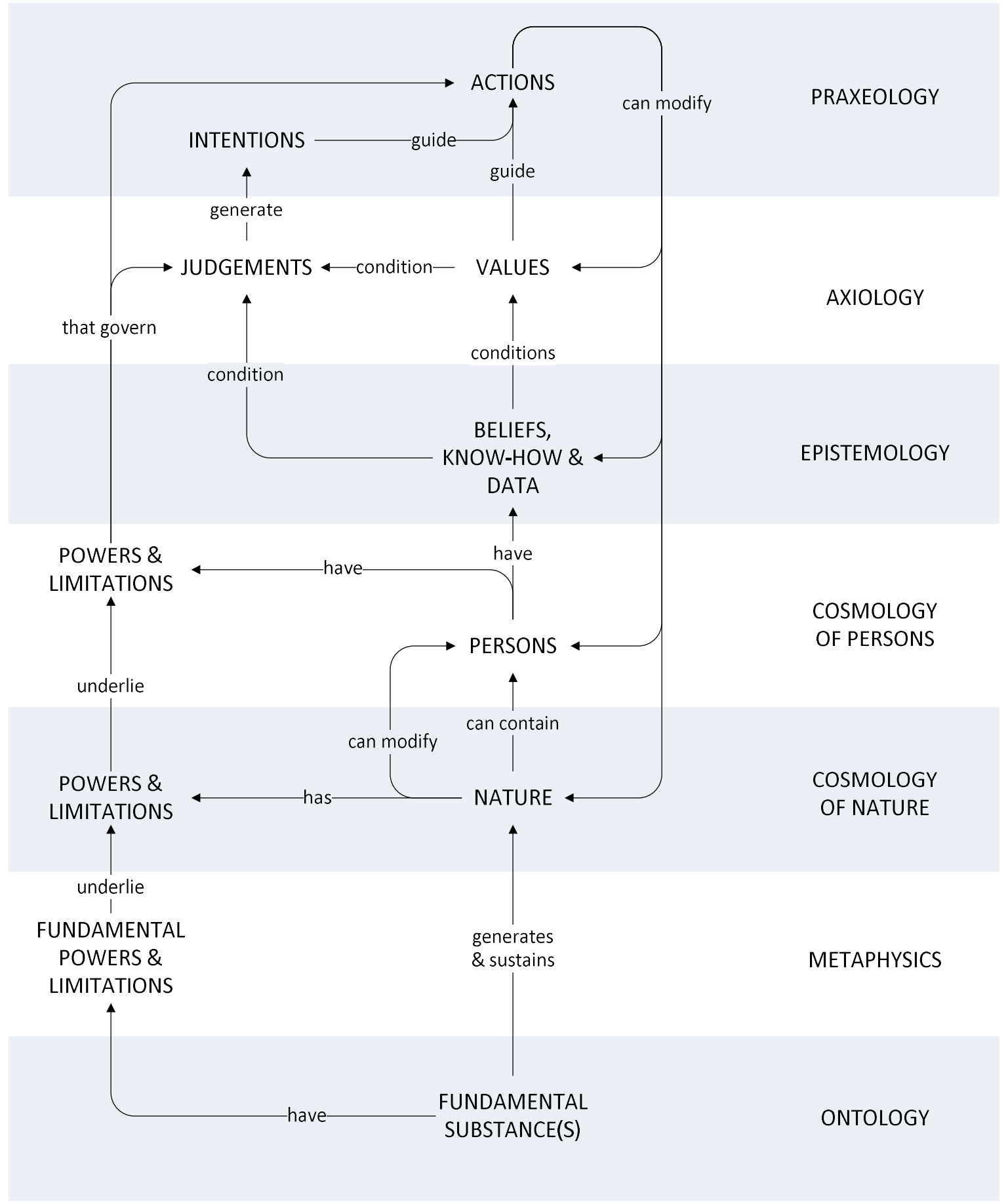

Figure 2. A systems model of the world from the perspective of the Worldview Inquiry Framework.

Second, the systemicity of worldviews holds important lessons about the dynamics of worldview change, e.g.,

(a) Because the worldview system strives towards coherence, we can understand the reasons for the stability of worldviews - their systemicity entails that they would resist incorporation of ideas or beliefs that do not fit in in a way that preserves the existing (approximate) coherence.

(b) We can understand why paradigm shifts are so rare and so dramatic. Being a deep conviction held by a group, paradigmatic worldviews are even more stable and resistant to change than individual worldviews. When the total body of available and credible (but worldview challenging) evidence 
becomes too large to easily ignore or credibly reject, and so has to be incorporated, the systemicity of the worldview/paradigm ensures a 'ripple effect', so that change propagates throughout the worldview/paradigm system to establish a new balance that renders the whole coherent again (as described in Thomas Kuhn's works [10,11]).

(c) From a systems point of view, the last point explains why paradigm change is the most powerful leverage point for bringing about change for a group, as proposed by Donella Meadows [73].

\section{The "General Inquiry Framework"}

\subsection{Generalizing the Worldview Inquiry Framework}

The Worldview Inquiry Framework can be generalized to produce a multi-purpose inquiry framework in the following way.

A worldview that is adequate for guiding a person though all life's potential scenarios will have to contain beliefs about every aspect of reality. According to the Worldview Inquiry Framework, there are six kinds of beliefs in a worldview (not seven, because the Worldview Inquiry Framework divided cosmological beliefs into two aspects). This entails that there are six aspects to reality, each of which one could have beliefs about. Knowledge is "warranted true belief," i.e., a belief counts as knowledge if it is believed, if what is believed is true, and if it is believed for valid reasons (a belief that is accidentally true is not knowledge). A worldview can contain many beliefs that do not count as knowledge, but relevant knowledge will always fit into a worldview. From this we can infer that there are potentially six kinds of knowledge one could have about reality, or any subset of reality, and thus potentially six kinds of knowledge one could seek about any actual situation. In this way we could envision a general framework for organizing knowledge about anything, or any scenario, based on the six categories employed in worldview beliefs. This suggests that we could inquire after these kinds of knowledge by posing general questions framed after the manner of the ones used in formulating a worldview. Having noted this possibility, we proceeded to devise a generalization of the Worldview Inquiry Framework, producing what we call the "General Inquiry Framework." We explain it below and then show how it can be tailored for application in different contexts such as problem solving, product design, and foundational research.

\subsection{General Questions for a General Inquiry Framework}

We develop this framework in two stages. The first step is generalize how the worldview component names are interpreted, so they reflect the kind of information that is at stake, rather than kinds of beliefs or kinds of disciplines. Most remain unchanged as terms except for the clarifications of the 'cosmology' terms. In a worldview, the primary concern is centered on the person whose worldview is at stake, for whom the worldview answers how they should live. The person and their nature, history and potential is therefore, in general terms, the "subject of interest" in a worldview (Cosmology II). To work out the foundations of the person's purpose and motivation, the worldview tries to work out the place of the person in "the grand scheme of things", that is to say, in general terms, their "context" (Cosmology I). Once we generalize by seeing the person as a special case of a "subject of interest" and their place in the world as a special case of the "context" of a subject of interest, we can generalize all the other categories, as shown in Figure 3. Apart from the subtext of Cosmology I and II the other terms are retained as they were but their focus is slightly altered, as made clear by insertions in brackets after the component labels and the forms of the questions following. The main change here is that, having established the categories of "Cosmology of Subject of Interest" and "Cosmology of Context", we can now recognize that both these categories are grounded in a more general "Area of Interest", which provides us with the foundational concepts needed via answers to ontological and metaphysical questions. The other terms are retained as they were but their focus is slightly altered, as made clear by insertions in brackets after the component labels and the forms of the questions following. 
The main change here is that, having established the categories of "Cosmology of Subject of Interest" and "Cosmology of Context", we can now recognize that both these categories are grounded in a more general area of interest, which provides us with the foundational concepts needed via answers to ontological and metaphysical questions. For example, if a scientist were to take "salamanders" as their subject of interest, and hence aquatic environments as "context", the "area of study" would be characterized by the core concepts of biology, as characterized by "biology's ontology" (broadly, answers to the question "what variety of biological entities exist and how are they identified?") and "biology's metaphysics" (broadly, answers the question "what are the powers and limitations of kinds of biological entities?").

Note that, as discussed before in the context of the Worldview Inquiry Framework, the context of the inquiry will determine in what sequence the inquiry components are addressed, and to what depth any component is explored.

\begin{tabular}{|c|c|c|c|}
\hline $\begin{array}{l}\text { Worldview } \\
\text { Inquiry } \\
\text { Component }\end{array}$ & & $\begin{array}{l}\text { General Inquiry } \\
\text { Component }\end{array}$ & Typical Information Component Questions \\
\hline Ontology & $\rightarrow$ & $\begin{array}{c}\text { Ontology (of area of } \\
\text { interest) }\end{array}$ & $\begin{array}{c}\text { What are the fundamental existents or fundamental } \\
\text { categories of thought for our area of interest? What variety of } \\
\text { things occurs in the area of interest? What features and } \\
\text { attributes identify them? }\end{array}$ \\
\hline Metaphysics & $\rightarrow$ & $\begin{array}{c}\text { Metaphysics (of area of } \\
\text { interest) }\end{array}$ & $\begin{array}{l}\text { What is the nature of the entities contained in the area of } \\
\text { interest? What are their generic powers and limitations? } \\
\text { What powers are unique to these entities? }\end{array}$ \\
\hline $\begin{array}{l}\text { Cosmology I } \\
\text { (cosmology of } \\
\text { nature) }\end{array}$ & $\rightarrow$ & $\begin{array}{l}\text { Cosmology I } \\
\text { (cosmology of context of } \\
\text { subject of interest) }\end{array}$ & $\begin{array}{l}\text { What is present in the context or environment of the subject } \\
\text { of interest? What are the capabilities of those entities? How } \\
\text { are they organized? How did that scenario come about and } \\
\text { how will/could it change? What are the relationships between } \\
\text { the specific subject and its context? How do they condition } \\
\text { each other? }\end{array}$ \\
\hline $\begin{array}{l}\text { Cosmology II } \\
\text { (cosmology of } \\
\text { persons) }\end{array}$ & $\rightarrow$ & $\begin{array}{l}\text { Cosmology II } \\
\text { (cosmology of subject of } \\
\text { interest) }\end{array}$ & $\begin{array}{l}\text { What specific or specialised thing is the particular subject of } \\
\text { interest? What are its defining attributes? How did/could the } \\
\text { subject of interest originate? How did/could it develop into } \\
\text { its present/desired state? How might/should it change in the } \\
\text { future, and what will/could become of it? }\end{array}$ \\
\hline Axiology & $\rightarrow$ & $\begin{array}{l}\text { Axiology (of subject of } \\
\text { interest) }\end{array}$ & $\begin{array}{l}\text { What is the importance or value of the specific subject of } \\
\text { interest's existence and behaviour? Why does it matter what } \\
\text { it does? }\end{array}$ \\
\hline Praxeology & $\rightarrow$ & $\begin{array}{c}\text { Praxeology (of subject of } \\
\text { interest) }\end{array}$ & $\begin{array}{c}\text { What functions can the specific subject of interest perform? } \\
\text { What is the meaning or purpose or relevance of its activities? } \\
\text { By what mechanisms are these outcomes achieved? }\end{array}$ \\
\hline Epistemology & $\rightarrow$ & $\begin{array}{l}\text { Epistemology (of area of } \\
\text { interest, and of the specific } \\
\text { subject of interest and its } \\
\text { context) }\end{array}$ & $\begin{array}{c}\text { What can we know about the subject of interest and its } \\
\text { context? What methods can reveal this information? How can } \\
\text { we assess the comprehensiveness and credibility of this } \\
\text { information? }\end{array}$ \\
\hline
\end{tabular}

Figure 3. Components for a General Inquiry Framework, based on worldview components. 
Table 3. Inquiry framework questions specialized for different contexts.

\begin{tabular}{|c|c|c|c|c|}
\hline Inquiry Framework Component & $\begin{array}{l}\text { Questions for Documenting } \\
\text { a Worldview }\end{array}$ & $\begin{array}{c}\text { Questions for Designing a } \\
\text { Product (" } X \text { ") }\end{array}$ & $\begin{array}{l}\text { Questions for Solving a } \\
\text { Problem ("Y") }\end{array}$ & $\begin{array}{c}\text { Questions for Investigating a } \\
\text { Phenomenon ("Z") }\end{array}$ \\
\hline Ontology (of area of interest) & $\begin{array}{l}\text { What kinds of substances exist most } \\
\text { fundamentally? What grounds the } \\
\text { existence of reality? }\end{array}$ & $\begin{array}{l}\text { What variety of products exists } \\
\text { in our area of interest? What are } \\
\text { their distinctive attributes? } \\
\text { What lies outside our } \\
\text { area/remit? }\end{array}$ & $\begin{array}{l}\text { What variety of problems exists } \\
\text { in our area of interest? What are } \\
\text { their distinguishing attributes? } \\
\text { What problems are not for us to } \\
\text { worry about? }\end{array}$ & $\begin{array}{l}\text { What variety of fundamental } \\
\text { existents is presumed to exist in our } \\
\text { area of study? Where is the } \\
\text { boundary of our area of concern? }\end{array}$ \\
\hline Metaphysics (of area of interest) & $\begin{array}{l}\text { What is the nature of the } \\
\text { fundamental existents? }\end{array}$ & $\begin{array}{l}\text { What is the nature of the things } \\
\text { in our area? What are the } \\
\text { powers and limitations of things } \\
\text { in our area of interest? }\end{array}$ & $\begin{array}{l}\text { What is the nature of the } \\
\text { problems in our area? What } \\
\text { effects do they have? What are } \\
\text { the limits of their influence? }\end{array}$ & $\begin{array}{l}\text { What is the presumed nature of the } \\
\text { fundamental existents in our area? } \\
\text { What are their presumed powers } \\
\text { and limitations? }\end{array}$ \\
\hline $\begin{array}{l}\text { Cosmology II } \\
\text { (cosmology of subject of interest) }\end{array}$ & $\begin{array}{l}\text { What is the scope, origin, } \\
\text { developmental history, } \\
\text { and potential of human beings? }\end{array}$ & $\begin{array}{l}\text { What specific kind of thing } \\
\left(\text { " } \mathrm{X}^{\prime \prime}\right) \text { are we asked to make? } \\
\text { How can we create Xs? How } \\
\text { can we sustain them? What can } \\
\text { become of them? }\end{array}$ & $\begin{array}{l}\text { What is the scope of our specific } \\
\text { problem }\left(" Y^{\prime \prime}\right) \text { ? How did it arise } \\
\text { and unfold? What will happen } \\
\text { if we do not intervene? What } \\
\text { about } Y \text { can we change? }\end{array}$ & $\begin{array}{l}\text { What is the nature of the } \\
\text { phenomenon under study? } \\
\text { Where does it occur? How does it } \\
\text { originate and develop? What is } \\
\text { its potential? }\end{array}$ \\
\hline Axiology (of subject of interest) & $\begin{array}{l}\text { What is important and why? } \\
\text { What makes something 'good'? }\end{array}$ & $\begin{array}{l}\text { Why should the } \mathrm{X} \text { be like that? } \\
\text { How may be (not) develop/ } \\
\text { produce it? }\end{array}$ & $\begin{array}{l}\text { Why is Y perceived as a } \\
\text { problem? Who are the } \\
\text { stakeholders what are } \\
\text { their values? }\end{array}$ & $\begin{array}{l}\text { Why does it matter what Zs are and } \\
\text { do? How may we (not) investigate } \\
\text { it? What value can we derive from } \\
\text { understanding it? }\end{array}$ \\
\hline Praxeology (of subject of interest) & $\begin{array}{l}\text { How should we live? What gives } \\
\text { meaning to our actions? How can } \\
\text { we achieve meaningful actions? }\end{array}$ & $\begin{array}{l}\text { What should the desired system } \\
\text { do/achieve? What mechanisms } \\
\text { could produce that? What } \\
\text { methods do we have for } \\
\text { designing such a thing? }\end{array}$ & $\begin{array}{l}\text { What actions or outcomes } \\
\text { would resolve the problem? } \\
\text { What mechanism should we } \\
\text { remove, adjust or install to } \\
\text { achieve the desired outcome? } \\
\text { How can we get this done? }\end{array}$ & $\begin{array}{l}\text { Why do Zs do what they do? } \\
\text { What functions do its behaviours } \\
\text { provide? By what mechanisms are } \\
\text { the functions attained? }\end{array}$ \\
\hline $\begin{array}{l}\text { Epistemology (of area of interest, } \\
\text { and of the specific subject of interest } \\
\text { and its context) }\end{array}$ & What/how can we (not) know? & $\begin{array}{l}\text { How could we know that } X \\
\text { solves the actual problem at } \\
\text { stake? How can we know that } X \\
\text { will or does function as } \\
\text { intended? What confidence can } \\
\text { we have in this knowledge? }\end{array}$ & $\begin{array}{l}\text { What/how can we learn about } \\
\text { Y? How can we know the } \\
\text { potential consequences of an } \\
\text { intervention? How confident } \\
\text { can we be in our understanding } \\
\text { of Y and the consequences of } \\
\text { our intervention? }\end{array}$ & $\begin{array}{l}\text { How can we gain understanding of } \\
\text { Zs? What methods are effective? }\end{array}$ \\
\hline
\end{tabular}




\subsection{Adapting the General Inquiry Framework for Different Contexts}

From Figure 3, it is now clear that the Worldview Inquiry Framework is a special case of the General Inquiry Framework, where the subject of interest (Cosmology II) is a person, the context of the subject of interest (Cosmology I) is everything in nature (which includes social and cultural systems), and the area of interest (Ontology) is ultimate reality (what some refer to as "the ground of being").

With the General Inquiry Framework in mind, we can now propose specialized kinds of questions to be asked in specific alternative scenarios, as shown in Table 3, adapted from the general questions given in Figure 3.

The specialized varieties of the General Inquiry Framework in Table 3 are illustrative only, and not meant to be exhaustive. However, given this example, an investigator could expand these examples or tailor the General Inquiry Framework for other scenarios.

It should be noted that multiple tailored inquiry frameworks could be applied in the same project. For example, a project may at the outset implement a Problem-Solving Inquiry Framework but then apply the Worldview Inquiry Framework to the stakeholders in that scenario and use a Product Design Inquiry Framework to explore potential contributions to a solution.

\section{Conclusions}

In this paper, we propose a comprehensive "Worldview Inquiry Framework" that can be used across research contexts where knowledge of worldviews is important. We discuss the systemicity of worldviews, and explain how this can help practitioners to find the roots of differences between stakeholders' perspectives. We propose a generalization of the Worldview Inquiry Framework to produce a "General Inquiry Framework" that can be used to guide an inquiry process in other contexts and illustrate how the general inquiry questions can be tailored for contexts such as worldview analysis, problem solving, product design, and fundamental research.

Author Contributions: The project was conceived and managed by D.R. J.B and D.R. contributed equally to the research and writing of the text. D.R. drew the diagrams.

Funding: Financial and material support for the project was provided by the Centre for Systems Philosophy, INCOSE and the University of Hull's Centre for Systems Studies.

Acknowledgments: We would like to thank Javier Calvo-Amodio and the attendees of our workshops and seminar events for useful discussions in developing the arguments presented in this paper. We are also grateful to two anonymous reviewers of this paper for their helpful comments, which have greatly aided us in improving the structure and clarity of this paper.

Conflicts of Interest: The authors declare no conflict of interest.

\section{References and Note}

1. Checkland, P. Systems Thinking, Systems Practice; Wiley: New York, NY, USA, 1993.

2. Jackson, M.C. Systems Thinking: Creative Holism for Managers; John Wiley \& Sons: Chichester, UK; Hoboken, NJ, USA, 2003.

3. Hall, M.L.W. Merging the World Views of Systems Science and Human Values. In Critical Issues in Systems Theory and Practice; Springer: Boston, MA, USA, 1995; pp. 131-135.

4. Maqsood, T.; Finegan, A.D.; Walker, D.H. Five Case Studies Applying Soft Systems Methodology to Knowledge Management; Queensland University of Technology: Brisbane, Australia, 2001.

5. Bergvall-Kareborn, B.; Mirijamdotter, A.; Basden, A. Basic principles of SSM modeling: An examination of CATWOE from a soft perspective. Syst. Pract. Action Res. 2004, 17, 55-73. [CrossRef]

6. Sillitto, H.; Martin, J.; Griego, R.; McKinney, D.; Arnold, E.; Godfrey, P.; Dori, D.; Krob, D.; Jackson, S. What do we mean by "system"?-System beliefs and worldviews in the INCOSE community. In Proceedings of the INCOSE International Symposium, Washington, DC, USA, 7-12 July 2018; p. 17.

7. Sillitto, H. Fellows Initiative on Definition of the terms "System" and "SE". Presented at the Systems Science Working Group during the International Workshops 2018 (IW18) of the International Council on Systems Engineering, Jacksonville, FL, USA, 20-23 January 2018. 
8. Kahneman, D. Maps of Bounded Rationality: A Perspective on Intuitive Judgment and Choice. In Les Prix Nobel: The Nobel Prizes 2002; Frängsmyr, T., Ed.; Nobel Foundation: Stockholm, Sweden, 2003; pp. 449-489.

9. Naugle, D. Worldview: The History of a Concept; Eerdmans: Cambridge, UK, 2002.

10. Kuhn, T. The Structure of Scientific Revolutions, 3rd ed.; University of Chicago Press: Chicago, IL, USA, 1996.

11. Kuhn, T. The Road since Structure; University of Chicago Press: Chicago, IL, USA, 2000.

12. Ashman, K.M.; Baringer, P.S. After the Science Wars; Routledge: London, UK, 2001.

13. Midgley, G. Towards a new framework for evaluating systemic and participative methods. In Proceedings of the 51st Annual Meeting of the ISSS, Tokyo, Japan, 5-10 August 2007; Volume 51.

14. Midgley, G. Towards a New Framework for Evaluating Systemic and Participative Methods. Joint Seminar of the UK Academy for Information Systems (UKAIS) in Conjunction with the Information Systems, Organisations and Society (ISOS) Research Group, University of Salford, Held on the 1 June 2011 at the University of Manchester, Salford, UK, 2011, Volume 51. Available online: http:/ /www.slideshare.net/ ukais/evaluating-participativesystemicmethodssalford2011 (accessed on 14 May 2013).

15. Burns, J. What is Beyond the Edge of the Known World? J. Conscious. Stud. 2003, 10, 7-28.

16. Kelly, E.F.; Kelly, E.W.; Crabtree, A.; Gauld, A.; Grosso, M.; Greyson, B. Irreducible Mind: Toward a Psychology for the 21st Century; Rowman \& Littlefield: Lanham, MD, USA, 2007.

17. Treffert, D. Extraordinary People: An Exploration of the Savant Syndrome; Bantam: New York, NY, USA, 1989.

18. Haufe, C. Why do funding agencies favor hypothesis testing? Stud. Hist. Philos. Sci. Part A 2013, 44, 363-374. [CrossRef]

19. Schwab, K. The Fourth Industrial Revolution; Portfolio Penguin: New York, NY, USA, 2017.

20. Kant, I.; Gregor, M.J. Critique of Judgment; Hackett: Indianapolis, IN, USA, 1987.

21. Hiebert, P.G. Transforming Worldviews: An Anthropological Understanding of How People Change; Baker Academic: Grand Rapids, MI, USA, 2008.

22. Sire, J.W. Naming the Elephant: Worldview as a Concept; IVP Academic: Downers Grove, IL, USA, 2004.

23. Emmons, R.A. The Psychology of Ultimate Concerns: Motivation and Spirituality in Personality, 1st ed.; Guilford Press: London, UK, 1999.

24. James, W. The Varieties of Religious Experience: A Study in Human Nature, being the Gifford Lectures on Natural Religion Delivered at Edinburgh in 1901-1902; [cited edition is 36th impression published in 1928]; Longmans Green: London, UK, 1902.

25. Danesh, H.B.; Clarke-Habibi, S. The Concept of Worldview. In Education for Peace Curriculum Manual; EFP-International Press: Vancouver, BC, Canada, 2007; pp. 29-60.

26. Wallace, W.A. The Modeling of Nature: Philosophy of Science and the Philosophy of Nature in Synthesis; The Catholic University of America Press: Washington, DC, USA, 1996.

27. Chesterton, G.K. Heretics; John Lane Co.: New York, NY, USA, 1905.

28. Wilby, J.M.; Rousseau, D.; Midgley, G.; Drack, M.; Billingham, J.; Zimmermann, R. Philosophical Foundations for the Modern Systems Movement. In Proceedings of the 17th Conversation of the International Federation for Systems Research, St. Magdalena/Linz, Austria, 27 April-2 May 2014; pp. 32-42.

29. De Witt, A.; de Boer, J.; Hedlund, N.; Osseweijer, P. A new tool to map the major worldviews in the Netherlands and USA, and explore how they relate to climate change. Environ. Sci. Policy 2016, 63, 101-112. [CrossRef]

30. Samples, K.R. A World of Difference: Putting Christian Truth-Claims to the Worldview Test; Baker Books: Grand Rapids, MI, USA, 2007.

31. Rousseau, D. Systems Philosophy and the Unity of Knowledge. Syst. Res. Behav. Sci. 2014, 31, 146-159. [CrossRef]

32. Hedlund-de Witt, A.; De Boer, J.; Boersema, J.J. Exploring inner and outer worlds: A quantitative study of worldviews, environmental attitudes, and sustainable lifestyles. J. Environ. Psychol. 2014, 37, 40-54. [CrossRef]

33. Halsmer, D. Application of the "Engineering Mindset" for Worldview Evaluation. In Proceedings of the ASEE Midwest Section Annual Meeting, Tulsa, OK, USA, 17-19 September 2008; p. 12.

34. Witt, A. Climate Change and the Clash of Worldviews: An Exploration of How to Move Forward in a Polarized Debate. Zygon 2015, 50, 906-921. [CrossRef]

35. Checkland, P.B.; Davies, L. The Use of the Term "Weltanschauung" in Soft Systems Methodology. J. Appl. Syst. Anal. 1986, 13, 109-115. 
36. Sire, J.W. The Universe Next Door: A Basic Worldview Catalog; IVP Academic: Downers Grove, IL, USA, 2009.

37. Smart, N. Worldviews: Cross Cultural Explorations of Human Beliefs, 3rd ed.; Prentice Hall: Upper Saddle River, NJ, USA, 2000.

38. Vidal, C. Wat is een wereldbeeld? [What is a worldview?]. In Nieuwheid Denken. De Wetenschappen en het Creatieve Aspect van de Werkelijkheid [Novel thoughts: Science and the Creative Aspect of Reality]; van Belle, H., van der Veken, J., Eds.; Acco Uitgeverij: Leuven, Belgium, 2008.

39. Aerts, D.; Apostel, L.; De Moor, B.; Hellemans, S.; Maex, E.; Van Belle, H.; Van der Veken, J. Worldviews: From Fragmentation to Integration; VUB Press: Brussels, Belgium, 1994.

40. Funk, K. What Is a Worldview? 2001. Available online: http://web.engr.oregonstate.edu/ funkk/Personal/ worldview.html (accessed on 1 June 2016).

41. Carvalho, J.J. Overview of the Structure of a Scientific Worldview. Zygon 2006, 41, 113-124. [CrossRef]

42. Elohim, J.-L. A General Systems WELTANSCHAUUNG (Worldview). 2000. Available online: http:/ / www. isss.org/weltansc.htm (accessed on 20 January 2016).

43. Glennan, S. Whose Science and Whose Religion? Reflections on the Relations between Scientific and Religious Worldviews. Sci. Educ. 2007, 18, 797-812. [CrossRef]

44. Leontiev, D.A. Approaching Worldview Structure with Ultimate Meanings Technique. J. Humanist. Psychol. 2007, 47, 243-266. [CrossRef]

45. Vidal, C. An Enduring Philosophical Agenda. Worldview Construction as a Philosophical Method. 2007. Available online: http:/ / cogprints.org/6048/ (accessed on 25 June 2012).

46. Vidal, C. Metaphilosophical criteria for worldview comparison. Metaphilosophy 2012, 43, 306-347. [CrossRef]

47. Wolters, A.M. On the idea of worldview and its relation to philosophy. In Stained Glass: Worldviews and Social Science; Marshall, P.A., Griffioen, S., Mouw, R.J., Eds.; University Press of America: Lanham, MD, USA, 1989; pp. 14-25.

48. Malham, P.B. Investigating the Structure and Functions of Worldview Assumptions. Ph.D. Thesis, University of Oregon, Eugene, OR, USA, 2017.

49. Goldberg, R.M. How our worldviews shape our practice. Confl. Resolut. Q. 2009, 26, 405-431. [CrossRef]

50. Rousseau, D. Reconciling Spirituality with the Naturalistic Sciences: A Systems-Philosophical Perspective. J. Stud. Spiritual. 2014, 4, 174-189. [CrossRef]

51. Rousseau, D. Foundations and a Framework for Future Waves of Systemic Inquiry. Presented at the 22nd European Meeting on Cybernetics and Systems Research (EMCSR 2014), 2014, Vienna, Austria. In Proceedings of the EMCSR 2014: Civilisation at the Crossroads-Response and Responsibility of the Systems Sciences, Book of Abstracts, Vienna, Austria, 30 March-1 April 2016; Wilby, J.M., Blachfellner, S., Hofkirchner, W., Eds.; EMCSR: Vienna, Austria, 2014; pp. 428-434.

52. Rousseau, D.; Billingham, J.; Wilby, J.M.; Blachfellner, S. The synergy between General Systems Theory and the General Systems Worldview. Syst. Spec. Issue Gen. Syst. Transdiscipl. 2016, 4, 61-75.

53. Hofkirchner, W.; Rousseau, D. Foreword. In General System Theory: Foundations, Development, Applications; Braziller: New York, NY, USA, 2015; pp. xi-xix.

54. Rousseau, D.; Billingham, J. Is there "Ultimate Stuff" and are there "Ultimate Reasons"? In The Foundational Questions Institute's 2012 Essay Competition: Questioning the Foundations (Finalist); FQXi: Decatur, GA, USA, 2012.

55. Rousseau, D. If minds are not just brains, what might they be? Presentation to the Scientific and Medical Network. Guildford, UK, 18 November 2009.

56. Rousseau, D. Minds, Souls and Nature: A Systems-Philosophical analysis of the Mind-Body Relationship in the light of Near-Death Experiences. Ph.D. Thesis, University of Wales Trinity Saint David, Lampeter, Wales, UK, 2011.

57. Rousseau, D. Anomalous Cognition and the Case for Mind-Body Dualism. In Extrasensory Perception: Support, Skepticism, and Science; vol. II Ch. 13; May, E.C., Marwaha, S.B., Eds.; Praeger: Santa Barbara, CA, USA, 2015; Volume 2, pp. 271-304.

58. Rousseau, D. General Systems Theory: Its Present and Potential [Ludwig von Bertalanffy Memorial Lecture 2014]. Syst. Res. Behav. Sci. Spec. Issue ISSS Yearb. 2015, 32, 522-533. [CrossRef]

59. Rousseau, D.; Wilby, J.M.; Billingham, J.; Blachfellner, S. General Systemology—Transdisciplinarity for Discovery, Insight, and Innovation; Springer: Kyoto, Japan, 2018. 
60. Rousseau, D. On the Architecture of Systemology and the Typology of Its Principles. Systems $2018,6,7$. [CrossRef]

61. Rousseau, D. "Systems Principles and Worldviews". Workshop presented in the Systems Science Working Group (SSWG). In Proceedings of the International Workshops 2018 (IW18) of the International Council on Systems Engineering, Jacksonville, FL, USA, 20-23 January 2018.

62. Rousseau, D. A Framework for Understanding Systems Principles and Methods. In Proceedings of the INCOSE International Symposium, Washington, DC, USA, 7-12 July 2018.

63. Billingham, J.; Rousseau, D. A new approach to designing operational teams in evolving contexts. Presented at the OR Society 60th Annual Conference, Lancaster University, Lancaster, UK, 11-13 September 2018.

64. Varzi, A.C. On Doing Ontology without Metaphysics. Philos. Perspect. 2011, 25, 407-423. [CrossRef]

65. Bunge, M. Political Philosophy: Fact, Fiction, and Vision; Transaction Publishers: New York, NY, USA, 2009.

66. Rousseau, D.; Billingham, J.; Calvo-Amodio, J. Systemic Semantics: A Systems Approach to Building Ontologies and Concept Maps. Systems 2018, in press.

67. Rapoport, A. General System Theory. In The International Encyclopedia of Social Sciences; Sills, D.L., Ed.; Macmillan \& The Free Press: New York, NY, USA, 1968; Volume 15, pp. 452-458.

68. Sillitto, H.; Martin, J.; Dori, D.; Griego, R.M.; Jackson, S.; Krob, D.; Godfrey, P.; Arnold, E.; McKinney, D. SystemDef13MAy18.docx. In Working Paper of the INCOSE Fellows Project on the Definition of "System"; INCOSE: San Diego, CA, USA, 2018.

69. Rosen, R. Life Itself: A Comprehensive Inquiry into the Nature, Origin, and Fabrication of Life; Columbia University Press: New York, NY, USA, 2005.

70. Rousseau, D. A Systems Model of Spirituality. Zygon J. Relig. Sci. 2014, 49, 476-508. [CrossRef]

71. Oderberg, D. The Metaphysical Foundations of Natural Law. In Natural Moral Law in Contemporary Society; Zaborowski, H., Ed.; The Catholic University of America Press: Washington, DC, USA, 2010; pp. $44-75$.

72. De Caro, M.; Macarthur, D. Naturalism and Normativity; Columbia University Press: New York, NY, USA, 2010.

73. Meadows, D.H. Thinking in Systems: A Primer; Chelsea Green: White River Junction, VT, USA, 2008.

(C) 2018 by the authors. Licensee MDPI, Basel, Switzerland. This article is an open access article distributed under the terms and conditions of the Creative Commons Attribution (CC BY) license (http:/ / creativecommons.org/licenses/by/4.0/). 